\title{
Олена Кризина
}

аспірантка кафедри регіональної політики науково-навчального інституту публічного управління та державної служби, Київський національний

університет імені Тараса Шевченка, м. Київ, Україна, е-таil: olena.kryzyna@gmail.com, https://orcid.org/0000-0002-9639-271X

\section{Наталія Кризина}

доктор наук з державного управління, професор, Заслужений лікар Украӥни, професор кафедри управління охороною здоров'я та публічного адміністрування, Наиіональний університет охорони здоров'я Украйни імені П.Л. Шупика, м. Київ, Україна, е-mail: kryzyna.np@gmail.com, https://orcid.org/0000-0003-2074-961X

\section{СУТНІСТЬ ОСНОВНИХ ПОНЯТЬ ДОСЛІДЖЕННЯ ДЕРЖАВНОГО УПРАВЛІННЯ ПАТОЛОГОАНАТОМІЧНОЮ СЛУЖБОЮ}

Анотація. Стратегія сталого розвитку “Україна - 2030” передбачає в рамках векторів руху реалізацію реформ та програм розвитку держави, та реформи системи охорони здоров'я: створення системи, орієнтованої на пацієнта, здатної забезпечити медичне обслуговування для всієх громадян України на рівні розвинутих європейських держав; підвищення особистої відповідальності громадян за власне здоров'я [1].

Дослідження проблеми державного управління патологоанатоміною службою (ПАС) України в умовах реформування медичної галузі зумовило необхідність проаналізувати наукові тлумачення основних понять: "публічне управління", "державне управління", "патологоанатомічна служба", "медичні кадри для функціонування патологоанатомічної служби".

У статті досліджено, що публічне управління формується і реалізується у сфері охорони здоров'я, залучаючи до суспільно-політичних процесів соціальні групи різного рівня та ступеня спільності. Таким чином, проведений аналіз сутності основних понять дослідження доводить, що публічне управління здійснюється через взаємодію суб'єктів та об'єктів в суспільних відносинах при прийнятті та реалізації управлінських рішень.

Виявлено, що класична теорія менеджменту у державному секторі реалізувалася на практиці через модель публічного адміністрування (англ. public administration), неокласична теорія менеджменту - через модель публічного управління (англ. - public management), сучасна теорія менеджменту через модель нового публічного управління (англ. - new public management). 
Публічне управління включаєв себе ту діяльність, яка забезпечує ефективне функціонування всієї системи органів державної влади та органів місцевого самоврядування і передбачає широке залучення різних зацікавлених сторін до розробки та реалізації державної політики.

При цьому зауважимо, що державне управління $є$ складовою публічного управління. Відповідно парадигма публічного управління має концептуально відображати теоретичні засади про якісні загальносуспільні зміни з урахуванням сучасних завдань реалізації нової політики державного управління [2].

ПАС України так само як і перебудова медичної галузі отримали свій імпульс в сучасному періоді реформування за останні роки. Зазначені терміни потребують докладного вивчення в Україні та систематизації найкращих зарубіжних практик. Важливо, удосконалюючи впроваджені наукові досягнення у сфері державного управління, наслідувати найкращі зарубіжні тенденції та практики і сприяти розвитку науки публічного управління ПАС в Україні.

Ключові слова: публічне управління, державне управління, патологоанатомічна служба, медичні кадри.

\title{
Olena Kryzyna
}

Postgraduate Student of the Regional Policy

of the Scientific-Educational Institute of Public Administration and Civil Service,

Kyiv National Taras Shevchenko University,

Kyiv, Ukraine, e-mail: olena.kryzyna@gmail.com, https://orcid.org/0000-0002-9639-271x

\section{Nataliia Kryzyna}

Doctor of Sciences of Public Administration, Professor, Honored Doctor of Ukraine, Professor of the Department of Health and Public Administration, National University of Health of Ukraine named after P.L. Shupika, Kyiv, Ukraine, e-mail: kryzyna.np@gmail.com, https://orcid.org/0000-0003-2074-961x

\section{THE ESSENCE OF THE BASIC CONCEPTS OF THE STUDY OF THE STATE ADMINISTRATION OF THE PATHOANATOMICAL SERVICE}

\begin{abstract}
Sustainable Development Strategy "Ukraine - 2030" provides within the framework of the movement vectors for the implementation of reforms and health development programs and health care reforms: the creation of a patient-oriented system capable of providing medical care for all Ukrainian citizens at the level of developed European states; Increasing the personal responsibility of citizens for its own health [1].

Investigation Problems of public administration by the Pathoanatomin Service of Ukraine in conditions of reforming the medical industry led to the need to analyze the
\end{abstract}


scientific interpretation of the basic concepts: "Public Administration", "Public Administration", "Pathoanatomical Service", "Medical frames for the functioning of the pathoanatomical service."

The article investigates that public administration is formed and implemented in the field of healthcare, involving social groups of different levels and degree of community in socio-political processes. Thus, an analysis of the essence of basic concepts of research proves that public administration is carried out through the interaction of subjects and objects in public relations in the adoption and implementation of managerial decisions.

It was revealed that the classical theory of management in the public sector was implemented in practice through the model of public administration (English - public administration), neoclassical management theory - through the model of public administration (English - public management), modern management theory - through the model of new public administration (English - New Public Management).

Public administration includes that activity that ensures effective functioning of the entire system of state authorities and local self-government bodies and provides for broad attraction of various stakeholders to the development and implementation of state policy.

It remarks that public administration is an integral part of public administration. Accordingly, the Public Administration paradigm has to conceptually reflect the theoretical principles of high-quality general-society changes taking into account modern tasks of implementing a new public administration policy [2].

The Pathoanatomical Service of Ukraine, as well as the restructuring of the medical industry received its impulse in the modern period of reform in recent years. These terms require a detailed study in Ukraine and systematization of the best foreign practices. It is important to improve the scientific achievements in the field of public administration, follow the best foreign trends and practices and promote the development of the science of public administration of the pathoanatomical service in Ukraine. MPD.

Keywords: public administration, state administration, pathoanatomical service,

Постановка проблеми. За визначенням ВООЗ, здоров'я має індивідуальне та суспільне значення і вважає, що публічне управління у сфері охорони здоров'я полягає у визначенні певних пріоритетів, запровадженні системи заходів, спрямованих на забезпечення збереження й розвиток фізіологічних $i$ психологічних функцій, оптимальної працездатності та соціальної активності всіх членів суспільства при максимальній біологічно можливій індивідуальній тривалості життя кожної особи [3].

Публічне управління формується і реалізується у сфері охорони здоров'я, залучаючи до суспільно-політичних процесів соціальні групи різного рівня та ступеня спільності. У Конституції України (ст. 5) чітко зазначено, що “народ здійснює владу безпосередньо i через органи державної влади та органи місцевого самоврядування" [4]. 
Отже, коли ми говоримо про публічну владу, то маємо на увазі владу, джерелом якої $є$ народ. Коли ми говоримо про публічне управління, то, відповідно, маємо на увазі управління, участь у якому бере народ.

В умовах реформування медичної галузі в Україні, питання державного управління ПАС набуває важливого значення, як для практикуючих лікарів так $\mathrm{i}$ для забезпечення навчального процесу з підготовки фахівців 3 даної дисципліни $і$ для удосконалення знань i вмінь при безперервному навчанні для надання якісних та ефективних медичних послуг пацієнтам на всіх рівнях системи охорони здоров'я України.

\section{Аналіз останніх досліджень та публікацій.}

Питаннями дослідження теоретичних та організаційних засад державного управління займалися такі вітчизняні вчені, як: В. Д. Бакуменко, П. І. Надолішній, Д. О. Безносенко, І. М. Варзар, В. М. Князєв, Ю. П. Сурмін, А. М. Михненко, Ю. В. Ковбасюк, В. П. Трощинський та інші.

Проблематикою дослідження функціонування ПАС України в умовах реформування медичної галузі, займалися багато вітчизняних та міжнародних експертів. До них належать праці вітчизняних та зарубіжних авторів, таких, як: C., ГичкаI. Горелик, С. Горюнова, В. Гринберг, В. Діброва, А. Дивиденко, Л. Джулиан, Б. Сшмуротов, А. Іскандаров, Г. Касымова, А. Котуза, Д. Кулдашев, А. Пахлеванзаде, Л. Роша, І. Сидоренко, В. Стеценко, 3. Сальников, С. Тейлор, В. Крисько, С. Шиман та ін.

Мета статті: обгрунтувати сутність основних понять державного управління патологоанатоміної служби України в умовах реформування медичної галузі/

Виклад основного матеріалу. Сучасний стан медичної галузі в Україні характеризується низькою ефективністю використання наявного матеріального та кадрового потенціалу, повільними темпами змін у впровадженні інноваційних методів та технологій діагностики та відсутністю розуміння впровадження стандартів і індикаторів якості та управління в наданні медичних послуг.

Відповідно до теорії публічного управління одні й ті самі управлінські інструменти, що максимізують ефективність та результативність роботи, можна використовувати як в управлінні уряду, так і у інших галузях. Належне публічне управління має бути сфокусоване на забезпечення спроможності для досягнення результатів [5].

У глосарії Програми розвитку Організації Об'єднаних Націй $(\mathrm{OOH})$ - термін "публічне управління" - це галузь практики та теорії, яка $є$ ключовою для публічного адміністрування та зосереджена на внутрішній діяльності державних установ, зокрема на вирішенні таких управлінських питань, як контроль, керівництво, планування, організаційне забезпечення, забезпечення інформаційними технологіями, управління персоналом, та оцінка ефективності" [5].

Володимир Даль виводить зміст терміна "публічний” з терміна "публіка" (від лат. publica - суспільство, народ, люди) і визначає його як всенародний, оголошений, явний, відомий; організований для публіки, суспільства, народний, загальнонародний, всенародний, вселюдний; всіма спільний, такий, що всім належить [6]. 
Провідний експерт 3 аналізу державної політики Олександр Кілієвич перекладає англійське слово public на українську мову як "громадський, публічний, державний” [7].

У “Новому тлумачному словнику української мови” слово “управляти” має такі тлумачення: спрямовувати діяльність, роботу кого-, чого-небудь; бути на чолі когось, чогось; керувати; користуючись кермом та іншими регулюючими пристроями, спрямовувати рух, хід, роботу чого-небудь; спрямовувати хід якогось процесу, впливати на розвиток, стан чого-небудь [8].

Пітер Ф.Друкер визначає управління як “специфічний вид діяльності, який перетворює неорганізований натовп на ефективну цілеспрямовану продуктивну групу" [8].

За визначенням Анрі Файоля - “управляти - це передбачати, організовувати, розпоряджатися, узгоджувати, контролювати” [9].

M.Х. Мескон у термін “управління” вкладає той самий зміст, що й інші теоретики у сфері управління: "Менеджмент - це процес планування, організації, мотивації та контролю працівників організації, які забезпечують досягнення їх цілей” [10].

Слід зауважити, що державне управління $є$ складовою публічного управління. Відповідно парадигма публічного управління має концептуально відображати теоретичні засади про якісні загальносуспільні зміни з урахуванням сучасних завдань реалізації нової політики державного управління. Тобто, розмежовувати значення “менеджмент" i “управління” не можна. [11].

Історія науки державного управління розпочалася у кінці XIX ст. “Державне управління - це цілеспрямований організаційний та регулюючий вплив держави на стан і розвиток суспільних процесів, свідомість, поведінку та діяльність особи i громадянина 3 метою досягнення цілей та реалізації функцій держави, відображених у Конституції та законодавчих актах, шляхом запровадження державної політики, виробленої політичною системою та законодавчо закріпленої, через діяльність органів державної влади, наділених необхідною компетенцією" [12].

Словник-довідник “Державне управління”, визначає "державне управління" як практичний, організуючий i регулюючий вплив держави на суспільну життєдіяльність людей з метою ії упорядкування, зберігання, або перетворення, що спирається на ії владну силу [13].

В основу визначень державного управління, які надаються більшістю українських науковців, покладено класичне розуміння управління в державному секторі, що було запропоноване Максом Вебером. Інтегрований підхід до управління, який використовується сучасною теорією менеджменту, розглядає "організацію як відкриту систему, яка постійно взаємодіє із зовнішнім середовищем, до якого має пристосуватися” [14].

“Державне управління - діяльність держави (органів державної влади), спрямована на створення умов для якнайповнішої реалізації функцій держави, основних прав і свобод громадян, узгодження різноманітних груп інтересів у суспільстві та між державою і суспільством, забезпечення суспільного розвитку відповідними ресурсами" [15]. 
В.Д. Бакуменко стверджує, що “розуміння сутності державного управління зазнало еволюції внаслідок розвитку демократії та громадянського суспільства у світі та зокрема в Україні. Відтак сьогодні аспект взаємодії держави i громадянського суспільства в державному управлінні є дуже важливим на відміну від традиційного бачення державного управління як організуючого і регулюючого впливу держави на суспільну життєдіяльність людей з метою іiі упорядкування, зберігання або перетворення, що спирається на їі владну силу” [16].

Сучасні тенденції розвитку сфери охорони здоров'я вказують на те, що необхідно кардинально змінити напрями в управлінні системою охорони здоров'я 3 метою чіткого розподілу управлінських (публічні службовці, керівники закладів охорони здоров'я, менеджери тощо) та лікарських посад. Структура охорони здоров'я України має три основних рівні: національний, регіональний та субрегіональний (місцевий), які представлені органами публічної влади (МО3, департаментами (управліннями) охорони здоров'я при обласних державних адміністраціях, районними державними адміністраціями, органами місцевого самоврядування), та закладами охорони здоров'я [17].

Систему управління охороною здоров'я в Україні можна розглядати на двох рівнях: внутрішньогалузевий рівень управління (від завідуючого відділенням до керівника закладу охорони здоров'я) та державний рівень управління (від головного спеціаліста управління охорони здоров'я до міністра охорони здоров'я) [18].

В сучасних умовах патологоанатомічна служба (ПАС) - в Україні забезпечує прижиттєву і посмертну діагностику хвороб, патологічних процесів, контроль якості лікувально-діагностичної роботи в закладах охорони здоров’я, підвищення кваліфікації лікарів лікувальної мережі, забезпечує органи статистики достовірною інформацією про причини смерті в лікувальних закладах. Інтенсивний розвиток медичних технологій разом зі зростанням очікувань споживачів медичних послуг вимагає суттєвих змін від патологоанатомічної служби України. ПАС тісно пов'язана 3 діяльністю всіх медичних спеціальностей. Патоморфологічне дослідження на сьогодні в світі є “золотим стандартом" прижиттєвої діагностики захворювань, де за даними аутопсій проводиться оцінка якості лікувального та діагностичного процесів в медичннх закладах будь-якої форми власності. ПАС України так само як і перебудова медичної галузі отримали свій імпульс в сучасному періоді реформування за останні роки.

ПАС змушена функціонувати в умовах розпорошення і без того обмеженого бюджетного фінансування між численними патологоанатомічними відділеннями комунальних закладів охорони здоров'я, які зберігають 3 радянських часів організаційну структуру та штатний розклад майже в незмінному вигляді попри автономізацію закладів охорони здоров’я внаслідок змін законодавства та скасування нормативно-правових актів, що визначали цю структуру та штати. Розпорошення бюджетного фінансування залишає патологоанатомічній службі можливість застосування лише рутинних методик морфологічного дослідження, які не завжди надають необхідну інформацію для призначення сучасного лікування, особливо онкопатології 
В сучасних умовах реформування медичної галузі, структура ПАС України потребує реорганізації. Найгострішою проблемою ПАС є проблема фінансування, яке здійснюється на даний час за «залишковим принципом»

В наказі МО3 України № 81, від 12.05 .1992 року "Про розвиток та удосконалення патологоанатомічної служби в Україні" дано таке визначення: "патологоанатомічна служба" вважається важливою частиною практичної охорони здоров'я, що забезпечує діагностику захворювань, підвищення кваліфікації лікарів та науково-практичний контроль лікарняної справи"

"патологоанатомічна служба" призначена для виконання прижиттєвої посмертної діагностики захворювань, вивчення етіології, патогенезу найбільш поширених недуг, контролю за якістю клінічної діагностики та ефективності лікувального процесу, а також удосконалення професійної підготовки лікарів.

Діяльність ПАС спрямована на реалізацію державної політики у сфері охорони здоров'я, що передбачає проведення заходів, спрямованих на: забезпечення прижиттєвої і посмертної діагностики хвороб, патологічних станів і процесів; забезпечення експертизи і контролю якості діагностики та лікування на основі клініко-патологоанатомічних співставлень на всіх рівнях надання медичної допомоги; розробку та впровадження сучасних методів прижиттєвої діагностики та оцінки ефективності лікування захворювань; забезпечення достовірних даних державної статистики смертності населення та смертельних ускладнень медичних дій; наукову розробку матеріалів патологоанатомічних досліджень; зниження захворюваності, інвалідності та смертності населення.

Пріоритетними напрямками розвитку патологоанатомічної служби в Україні є:

- покращення матеріально-технічного, фінансового, кадрового і ресурсного забезпечення організаційних структур ПАС;

- технічна модернізація та оптимізація роботи закладів і підрозділів ПАС на принципах організаційної, професійної та економічної ефективності;

- розвиток і удосконалення прижиттєвої патоморфологічної діагностики захворювань;

- впровадження в роботу закладів i підрозділів ПАС сучасних високотехнологічних імуногістохімічних, молекулярно-генетичних, ультраструктурних методів досліджень, інформаційних, телекомунікаційних технологій і телепатології;

- стандартизація порядку, автоматизація i комплексне інформаційне забезпечення патологоанатомічних досліджень та технологічних лабораторних процесів, розробка i впровадження системи технологічних стандартів, уніфікованих протоколів на основі сучасних досягнень науки, міжнародних стандартів і протоколів;

- удосконалення організаційних структур закладів i підрозділів ПАС, створення та розвиток ПАБ, консультативно-діагностичних i peферентних центрів патоморфологічної діагностики;

- забезпечення якості патологоанатомічної діагностики шляхом ліцензування, атестації, акредитації, стандартизації і сертифікації патологоанатомічних закладів (підрозділів), впровадження систем контролю та 
управління якості патологоанатомічних досліджень відповідно до міжнародних стандартів якості.

Основою діяльності ПАС, $є$ встановлення морфологічного субстрату захворювань, патологічних процесів і станів на різних рівнях структурної організації (організмовий, системний, органний, тканинний, клітинний, ультраструктурний, молекулярний) та стадіях хвороби.

Нажаль, ще й досі, ПАВ окремих закладів охорони здоров'я розташовані в будівлях в аварійному стані без водопостачання та водовідведення, в деяких закладах патологоанатомічні розтини проводять не лікарі-патологоанатоми, а сумісники лікарі-спеціалісти 3 інших спеціальностей, у багатьох закладах охорони здоров'я на патологоанатомічний розтин направляється лише частина померлих $з$ тих, які підлягають розтину.

В умовах проведення медичної реформи бюджетне фінансування отримають лише акредитовані діагностичні лабораторії, тобто ті, які мають приміщення, оснащення, кадровий склад та організацію виробничих процесів згідно 3 акредитаційними вимогами. Інакще, це може неминуче призвести до втрати нею фінансування при переході 3 медичної субвенції до оплати медичної послуги. Єдиним способом вирішення цієї проблеми в межах існуючого поки що фінансування є концентрація бюджетних коштів в ПАБ, яке на сучасному рівні проводитиме патологоанатомічні дослідження для всіх закладів охорони здоров'я областей та надаватиме платні послуги згідно з договорами.

Ключовою фігурою у ПАС є лікар-патологоанатом. Ефективність роботи лікаря-патологоанатома залежить від його професійних та особистих якостей: високого професіоналізму, виконавчої дисципліни, вміння логічно мислити, здійснювати об’єктивні, науково обгрунтовані і достовірні патологоанатомічні дослідження та клініко-патологоанатомічний аналіз, ініціативи, організаторських здібностей та вміння спілкування з людьми, відповідальності за виконану роботу, дотримання норм лікарської етики, гуманності, вихованості, високого рівня культури тощо [19].

Посади лікарського персоналу, середнього, молодшого медичного та іншого персоналу патологоанатомічних закладів (центрів, бюро), патологоанатомічних підрозділів (відділень, лабораторій) встановлюються відповідно до рекомендованих штатних нормативів закладів охорони здоров'я із врахуванням обсягу роботи, категорій складності патологоанатомічних розтинів, патоморфологічного дослідження операційного і біопсійного матеріалів, норм часу, кількості медичних закладів, що обслуговує патологоанатомічне бюро (центр) або патологоанатомічне відділення (лабораторія) тощо [20].

Неможливо вимагати від патологоанатома незалежного, об'єктивного та неупередженого оцінювання якості надання медичної допомоги окремими лікарями-спеціалістами у випадках смерті хворих, якщо він працює в одному закладі охорони здоров'я з цими самими лікарями-спеціалістами. До того ж, не у всіх комунальних закладів охорони здоров'я проводить відео- та аудіофіксація патологоанатомічного розтину, бо чинне законодавство не висуває такої вимоги, а бюджет не передбачає на це коштів.

У сьогоднішніх соціально-економічних умовах нашої країни на основі 
аналізу переваг і недоліків централізованої та децентралізованої моделей системи органів ПАС упровадження централізованої моделі побудови ПАС України видається більш привабливим. Вагомими перевагами при цьому можуть стати оптимізація фінансування та забезпечення служби належним устаткуванням, посилення організаційно-методичної ролі служби, наявність контролю за станом діагностики й адекватністю лікування в 303, підвищення рівня професійних якостей лікарів-патологоанатомів та працівників, тощо.

\section{Висновки.}

1. Отже, саме класична модель управління у державному секторі набуває визнання в Україні, де й досі використовується термін "державне управління", який не є тотожним терміну “публічне управління" але за своїм значенням є ближчим до терміну “публічне адміністрування". Дуже часто два piзних терміни public administration (публічне адміністрування) та public management (публічне управління) перекладаються 3 англійської мови на українську як “державне управління”. Вважається, що основними рисами державного управління є його владний характер, витоками якого є державна воля та поширеність на все суспільство. Трактування державного управління як владного впливу держави на суспільну систему є найкращою ілюстрацією того, як в Україні сприймається та розуміється значення терміна "державне управління”. Ключовим аспектом державного управління є держава, у той час як ключовим аспектом публічного управління є народ. У посттоталітарних країнах ведуться наукові дискусії щодо переходу від державного управління до публічного управління.

2. Зважаючи на вищезазначене, можемо констатувати, що новий зміст, що вкладається у термін “державне управління”, є наближеним до змісту, що вкладається у такий новий термін, як “публічне управління". Еволюція менеджменту у державному секторі привела до появи таких нових понять, як “належне врядування" (good governance), “глобальне врядування" (global governance), “зайняте врядування” (engaged governance) тощо.

3. В сучасних умовах для виконання ПАС України завдань і функцій необхідні: модернізація матеріально-технічної бази служби, ii відповідність рівню розвитку світової медичної науки i практики охорони здоров'я; незалежність професійної діяльності фахівців; постійне належне фінансування, матеріально-технічне i кадрове забезпечення на пріоритетних засадах; впровадження i використання в патологоанатомічній практиці сучасних високотехнологічних діагностичних методів імуногістохімії і молекулярної патології, автоматизованого гістологічного лабораторного обладнання, сучасних інформаційних, телекомунікаційних технологій і телепатології; впровадження систем контролю і управління якості патологоанатомічних досліджень відповідно до міжнародних стандартів якості (стандартів ISO тощо); централізація та створення патологоанатомічного центру (інституту) патологоанатомічних досліджень в Україні. Тому перспектива розвитку ПАС бачиться не тільки у виділенні іiі в самостійну ланку охорони здоров'я, а й в уніфікації форм організації та методів діяльності. Створення на базі кафедр патологічної анатомії 
медичних вишів навчально-науково-практичних об'єднань дасть змогу уніфікувати й оптимізувати всі напрями діяльності ПАС.

\section{Jimepamypa:}

1. Стратегія сталого розвитку "Україна 2030" [Електронний ресурс]. - Режим доступу: https://ips.ligazakon.net/document/view/kr150213

2. Глоссарий терминов, используемых в серии «Здоровье для всех». Женева : ВОЗ, 1984. № 1-8. URL: http://www.who.int

3. Конституція України. - Режим доступу : http://zakon.rada.gov.ua/

4. Глосарій Програми розвитку ООН. - Режим доступу : http://www.unpan.org/Directories/ UNPublicAdministrationGlossary

5. Даль В. И. Толковый словарь живого великорусского языка : в 4 т. / В. И. Даль. - М. : Рус. яз., 1999. - Т. 3: П. - 1999. - С. 535., с. 535/

6. Кілієвич О. Англо-український глосарій термінів і понять з аналізу державної політики та економіки / О. Кілієвич. - К. : Вид-во Соломії Павличко “Основи”, 2003. - 510 с., с. 292/

7. Новий тлумачний словник української мови : у 4 т. 42000 слів / уклад. : В. Яременко, О. Сліпушко. - К. : Аконіт, 2000. - Т. 3 (О-Р). - 927 с., с. 642/

8. Peter F. Drucker. The Practice of Management, Butterworth-Heinemann, 1999. - 399 p., c. 4/

9. Fayol, Henri (1916), Administration industrielle et générale; prévoyance, organisation, commandement, coordination, controle, Paris, H. Dunod et E. Pinat. - Режим доступу : http://www.worldcat.org/, c. 8/

10. Management / Michael H. Mescon, Michael Albert, Franklin Khedouri. - 3rd ed. Cambridge, MA [etc.], 1988. - 349 p, с. 16/ Режим доступу : http://www.management.com.ua/

11. Державне управління : навч. посіб. / А. Ф. Мельник, О. Ю. Оболенський, А. Ю. Васіна, Л. Ю. Гордієнко ; за ред. А. Ф. Мельник. - К. : Знання-Прес, 2003. - 343 с., с. 32/

12. Державне управління та державна служба : словник-довідник / уклад. О. Ю. Оболенський. - К. : КНЕУ, 2005. - 480 с., с. 94/

13. Державне управління : словник-довідник / уклад. : В. Д. Бакуменко (кер. творчого кол.), Д. О. Безносенко, І. М. Варзар та ін. ; за заг. ред. В. М. Князєва, В. Д. Бакуменка. - К. : Вид-во УАДУ, 2002. - 228 с., с. 63/

14. Bouckaert G. Modernizing the Rechtsstaat: Paradoxes of the Management Agenda / G. Bouckaert. - Berlin : Duncker \& Humblot, 2002., c. 26/

15. Енциклопедичний словник $з$ державного управління / уклад. : В. Д. Бакуменко, А. М. Михненко та ін. ; за ред. Ю. В. Ковбасюка, В. П. Трощинського, Ю. П. Сурміна. - К. : НАДУ, 2010. - 820 с., с. 150/

16. Васюк Н. О., Савіна Т. В. Публічна політика щодо підготовки керівних кадрів у сфері охорони здоров'я : сутність понять. Кадрова політика у сфері охорони здоров'я в умовах загроз національній безпеці України : матеріали щоріч. Всеукр. наук.-практ. конф. за міжнар. участю, 23 берез. 2017 р. Київ : ТОВ «ДКС-Центр», 2017. С. 8-13

17. Князевич В. М., Васюк Н. О., Савіна Т. В. Публічна служба у сфері охорони здоров'я в Україні та світі : нормативно-правовий аспект. Інвестиції : практика та досвід. 2017. № 14. C. 74-78.

18. Проект накаку MO3 України "Про патологоанатомічну службу" (оприлюднено 04.02.2011року). URL/http://old.moz.gov.ua/ua/portal/dh_20110204_pp.htme].

19. Методичні рекомендоції MO3 України №30.17/39.17, від 11.042011 року "Організація роботи закладів і підрозділів патологоанатомічної служби України"/

20. Медичні лабораторії. Вимоги до якості та компетентності (EN ISO 15189:2015, IDT): ДСТУ ISO 15189 : 2015. - [Чинний від 2016.01.01]. - К. : Держспоживстандарт України, 2016. IV. - 17 с. - (Національний стандарт України) 


\section{References:}

1. Rozporiadzhennia Kabinetu Ministriv Ukrainy "Pro zatverdzhennia planu zakhodiv z vykonannia Prohramy diialnosti Kabinetu Ministriv Ukrainy ta Stratehii staloho rozvytku "Ukraina - 2020" u 2015 rotsi" : vid 4 bereznia 2015 r. N 213-r [Order of the Cabinet of Ministers of Ukraine "On approval of the action plan for the implementation of the Program of Activities of the Cabinet of Ministers of Ukraine and the Sustainable Development Strategy "Ukraine - 2020" in 2015" from March 4, 2015 N 213-r]. ips.ligazakon.net. Retrieved from https://ips.ligazakon.net/document/view/kr150213 [in Ukrainian].

2. Glossarii terminov, ispolzuemykh v serii «Zdorove dlia vsekh»[Glossary of terms used in the "Health for All" series]. (1984). Geneva: WHO. Retrieved from http://www.who.int [in Russian].

3. Konstytutsiia Ukrainy : vid 28.06.1996, № 254k/96-VR [The Constitution of Ukraine from 28.06.1996, № 254k/96-VR]. zakon.rada.gov.ua. Retrieved from https://zakon.rada.gov.ua/laws/show/ 254k/96-vr\#Text [in Ukrainian].

4. Hlosarii Prohramy rozvytku OON [Glossary of the UN Development Program]. www.unpan.org. Retrieved from http://www.unpan.org/Directories/UNPublicAdministrationGlossary [in English].

5. Dal, V. I. (1999). Tolkovyi slovar zhivogo velikorusskogo iazyka [Explanatory dictionary of the living Great Russian language]. (Vol. 3). Moscow: Rus. iaz. [in Russian].

6. Kiliievych, O. (2003). Anhlo-ukrainskyi hlosarii terminiv i poniat z analizu derzhavnoi polityky ta ekonomiky [Anglo-ukrainian glossary of terms and concepts from the analysis of state policy and economy]. Kyiv: Vyd-vo Solomii Pavlychko "Osnovy" [in Ukrainian].

7. Yaremenko, V., Slipushko, O. (2000). Novyi tlumachnyi slovnyk ukrainskoi movy [New explanatory dictionary of the Ukrainian language]. (Vol. 3). Kyiv: Akonit [in Ukrainian].

8. Drucker, P. F. (1999). The Practice of Management. Butterworth-Heinemann [in English].

9. Fayol, H. (1916). Administration industrielle et générale; prévoyance, organisation, commandement, coordination, controle. Paris: H. Dunod et E. Pinat [in French].

10. Mescon, M. H., Albert, M., Khedouri, F. (1988). Management. (3rd ed.). Cambridge. Retrieved from http://www.management.com.ua/ [in English].

11. Melnyk, A. F., Obolenskyi, O. Yu., Vasina, A. Yu., Hordiienko, L. Yu. (2003). Derzhavne upravlinnia [Public administration]. Kyiv: Znannia-Pres [in Ukrainian].

12. Obolenskyi, O. Yu. (2005). Derzhavne upravlinnia ta derzhavna sluzhba [Public administration and public service]. Kyiv: KNEU [in Ukrainian].

13. Bakumenko, V. D., Beznosenko, D. O., Varzar, I. M., et al. (2002). Derzhavne upravlinnia [Public administration]. V. M. Kniaziev, V. D. Bakumenko (Eds.). Kyiv: Vyd-vo UADU [in Ukrainian].

14. Bouckaert, G. (2002). Modernizing the Rechtsstaat: Paradoxes of the Management Agenda. Berlin: Duncker \& Humblot [in English].

15. Bakumenko, V. D., Mykhnenko, A. M., et al. (2010). Entsyklopedychnyi slovnyk z derzhavnoho upravlinnia [Encyclopedic dictionary of public administration]. Yu. V. Kovbasiuk, V. P. Troshchynskyi, Yu. P. Surmin (Eds.). Kyiv: NADU [in Ukrainian].

16. Vasiuk, N. O., Savina, T. V. (2017). Publichna polityka shchodo pidhotovky kerivnykh kadriv u sferi okhorony zdorovia : sutnist poniat [Public policy for the training of managers in the field of health care: the essence of concepts]. Kadrova polityka u sferi okhorony zdorovia v umovakh zahroz natsionalnii bezpetsi Ukrainy - Personnel policy in the field of health care in the face of threats to the national security of Ukraine : Proceedings of annual All-Ukrainian scientific-practical conference with international participation. (pp. 8-13). Kyiv: TOV «DKS-Tsentr» [in Ukrainian].

17. Kniazevych, V. M., Vasiuk, N. O., Savina, T. V. (2017). Publichna sluzhba u sferi okhorony zdorovia v Ukraini ta sviti: normatyvno-pravovyi aspekt [Public service in the field of health care in Ukraine and the world: regulatory and legal aspect]. Investytsii : praktyka ta dosvid - Investments: practice and experience, 14, 74-78 [in Ukrainian].

18. Proekt nakaku MOZ Ukrainy "Pro patolohoanatomichnu sluzhbu" [Draft order of the Ministry of Health of Ukraine "On the pathological service"]. (2011). old.moz.gov.ua. Retrieved from http://old.moz.gov.ua/ua/portal/dh_20110204_pp.htme [in Ukrainian].

19.Metodychni rekomendotsii MOZ Ukrainy "Orhanizatsiia roboty zakladiv $i$ pidrozdiliv patolohoanatomichnoi sluzhby Ukrainy" : vid 11.04.2011 roku, №30.17/39.17 [Methodical recommendations of the Ministry of Health of Ukraine "Organization of work of institutions and subdivisions of the pathological anatomical service of Ukraine" from 11.04.2011, №30.17/39.17]. [in Ukrainian]. 
20. Medychni laboratorii. Vymohy do yakosti ta kompetentnosti [Medical laboratories. Requirements for quality and competence]. (2016). (EN ISO 15189:2015, IDT): DSTU ISO 15189 from January 1, 2016. Kyiv: Derzhspozhyvstandart Ukrainy [in Ukrainian]. 